https://doi.org/10.5559/di.27.1.09

\section{Janice Wearmouth SPECIAL EDUCATIONAL NEEDS AND DISABILITIES IN SCHOOL: A CRITICAL INTRODUCTION}

New York: Bloomsbury Academic, 2017., 280 str.

Profesorica na Sveučilištu u Bedfordshireu, Janice Wearmouth, objavila je u izdanju nakladničke kuće Bloomsbury Academic prvo izdanje knjige Posebne obrazovne potrebe $i$ poteškoće u školi: kritički osvrt (Special Educational Needs and Disabilities in School: A Critical Introduction). Knjiga je napisana na engleskom jeziku i sadrži 280 stranica. Sastoji se od predgovora, 10 poglavlja, 9 grafičkih prikaza, 3 tablice te referenci $i$ indeksa pojmova.

U prvom poglavlju autorica objašnjava pojam učenika s poteškoćama kroz razne pristupe njihovu poučavanju na području Ujedinjenoga Kraljevstva. Ona opisuje stavove školskog osoblja prema učenicima s poteškoćama u razvoju: medicinski model ili model deficita (medical or deficit model), model milosrđa (charity cases) te socijalni model (social context). Kao poteškoće ostvarivanja socijalnoga modela (social context) navodi ekonomske faktore, vladinu politiku, institucionalnu praksu te društveno neprihvatljivu okolinu. Teoretiziraju se neki od modela učenja: biheviorizam, konstruktivizam i socijalni konstruktivizam.

U drugom poglavlju autorica daje prikaz povijesnog razvoja institucionalne podrške za učenike s poteškoćama u razvoju na prostoru Ujedinjenoga Kraljevstva u osamnaestom, devetnaestom i dvadesetom stoljeću kroz vrijeme segregacije, integracije i inkluzije. Ona upozorava na različitost koncepta pojma učenici s poteškoćama u razvoju na prostoru Engleske, Walesa, Sjeverne Irske i Škotske. Tako se u Engleskoj, Walesu i Sjevernoj Irskoj učenike s poteškoćama u razvoju definira kao djecu koja imaju poteškoće $\mathrm{u}$ učenju (learning difficulty), a na prostoru Škotske obrazovanje učenika s poteškoćama uključuje obrazovnu podršku (additional support needs) te razvoj osobnosti, talenata, mentalnog i tjelesnog razvoja učenika.

Autorica upozorava na različitost zakona u Ujedinjenom Kraljevstvu koji reguliraju obrazovnu podršku za učenike s poteškoćama u razvoju. Tako je to u Engleskoj Plan obrazovanja, zdravstva i socijalne skrbi (Education, Health and Care Plan), na prostoru Walesa Unapređivanje partnerstva djece i mladih s poteškoćama u razvoju (Forward in Partnership for Children and Young People with Additional Needs), u Sjevernoj Irskoj Zakon o obrazovanju učenika s poteškoćama u razvoju (Special Educational Needs and Disability Bill), a u Škotskoj Zakon o podršci u učenju (Additional Support for Learning Act). Ona navodi poteškoće koje mogu dovesti do potrebe za obrazovnom podrškom kod učenika: okolina, obiteljske okolnosti, zdravstvene poteškoće te socijalni ili emocionalni faktori.

S obzirom na to autorica razmatra primjenu Kodeksa prakse (Code of Practice) kao instrumentarija za identifikaciju i procjenu djece s poteškoćama $u$ razvoju na prostoru Ujedinjenoga Kraljevstva. Kodeks prakse Sjeverne Irske sastoji se od identifikacije učenika s poteškoćama u razvoju, prikupljanja potrebnih podataka i utvrđivanja primjerenog oblika podrške, uključivanja stručnjaka izvan škole te razmatranja potrebe stručne procjene i podrške od strane Školskog odbora.

Kodeks prakse Walesa razlikuje podršku (School Action) te dodatnu edukacijsko-rehabilitacijsku podršku (School Action Plus). Podrška uključuje individualnu obra- 
zovnu potporu te suradnju svih sudionika odgojno-obrazovnoga procesa, a sve zbog procjene uspješnosti napretka u svladavanju predviđenih ishoda učenja. Dodatna edukacijsko-rehabilitacijska podrška predviđa uključivanje vanjskih stručnjaka kao obrazovne podrške učeniku. Kodeks prakse Škotske temelji se na osobnom planiranju učenja, koje uključuje mogućnosti i sposobnosti učenika, a temelji se na njegovim jakim stranama u skladu s ciljevima individualiziranoga odgojno-obrazovnog programa.

U trećem poglavlju autorica govori o osiguravanju inkluzivne učionice vrednovanjem školskog ozračja za učenje, načina i oblika poučavanja te procjenom inkluzivne potpore za učenike s poteškoćama $u$ ponašanju. Ona uključuje inicijalnu procjenu učenika, praćenje njegova ponašanja $\mathrm{u}$ razrednom odjelu i otklanjanje neprihvatljivih oblika ponašanja. Procjena učenika s poteškoćama mora se temeljiti na iskustvu učitelja, informacijama škole o napretku i dostignućima učenika, individualnom razvoju učenika, stavovima i iskustvima roditelja, učenikovim pogledima te savjetima vanjskih stručnjaka.

Podatci za procjenu učenika temelje se na formativnom procjenjivanju, kriterijima poučavanja te standardiziranim testovima. Formativno procjenjivanje ovisi o osiguravanju pozitivne povratne informacije, aktivnom uključivanju učenika u proces učenja, prilagođavanju procesa učenja rezultatima inicijalne procjene te utjecaju procjene na učenikovu motivaciju i samopoštovanje. Kriteriji poučavanja temelje se na učenikovim jakim stranama i slabostima te individualnim potrebama učenika u učenju i poučavanja u skladu s ishodima učenja. Standardizirani testovi temelje se na konceptu mjera raspršenosti ili standardne devijacije te valjanosti i pouz- danosti. Autorica navodi rangiranje i koncept čitanja u skladu s dobi kao važne komponente ovih testova. Kao prednosti naglašavaju se usporedba rezultata učenika ispod i iznad prosjeka u raznim kurikularnim područjima te primjerenost dobi, a poteškoće su nedostatak motivacije kod učenika koji postignu slabije rezultate na testiranju.

Praćenje ponašanja učenika s poteškoćama u razvoju temelji se na dva bihevioristička okvira. Prvi, Watkinsov i Wagnerov okvir, identificira ponašanje učenika praćenjem usvajanja nastavanih sadržaja u razrednom i školskom ozračju. Drugi okvir uključuje funkcionalnu procjenu i istražuje uzroke, posljedice te kontekst ponašanja učenika. Osim okvira za praćenje, učitelji u razrednom odjelu listom procjene te vremensko-intervalnim uzorkovanjem procjenjuju ponašanje učenika.

Kurikularno planiranje učenika s poteškoćama autorica temelji na individualiziranom odgojno-obrazovnom planu. Individualizirani odgojno-obrazovni plan $u$ Ujedinjenom Kraljevstvu važan je model planiranja poučavanja učenika s poteškoćama u razvoju, a temelji se na Kodeksu prakse te konceptu učeničke putovnice ( $p u$ pils passport). Koncept učeničke putovnice sastoji se od inicijalne procjene, učenikovih slabosti i jakih strana, razlikovnoga kurikuluma te osnovnih podataka o učeniku. O njoj mora biti obaviješten roditelj, a učenik je nosi na nastavni sat kako bi učitelj prilagodio ishode učenja mogućnostima i sposobnostima učenika.

U četvrtom poglavlju autorica je na temelju Kodeksa prakse svrstala engleske učenike s poteškoćama u razvoju u četiri područja: komunikacija i interakcija, kognitivne sposobnosti, socijalno, emocionalno i mentalno zdravlje, senzorne i tjelesne potrebe djeteta.

U komunikaciji i interakciji autorica navodi poučavanje engleskog kao drugoga stranog jezika za inojezične učenike, razvoj govora i komunikacije te podrške za učenike sa semantičko pragmatičnim poremećajem. Ona upozorava na važnost alternativno augmentativne komunikacije, sistema komunikacije razmjenom slika, sim- 
BR. 1

STR. 179-187

bola ili prikaza pri razvoju govora i komunikacije učenika.

Kognitivne sposobnosti autorica razmatra u kontekstu umjerenih intelektualnih poteškoća, poremećaja autističnoga spektra, težih i teških intelektualnih poteškoća te Downova sindroma. Ona predlaže i strategije podrške za pojedine vrste poteškoća u razvoju. Stoga se za učenike s umjerenim intelektualnim poteškoćama predlaže poučavanje bihevioralnim pristupom te skelom učenja, a za učenike s poremećajem autističnoga spektra poučavanje TEACCH metodom. Za učenike s težim i teškim intelektualnim poteškoćama te djecu sa Downovim sindromom autorica upućuje na kontinuirani razgovor kroz međusobnu interakciju razvojem govora i jezika.

Na području socijalnog, emocionalnog i mentalnog zdravlja djeteta autorica upućuje na strategije podrške kod učenika s poremećajem u ponašanju, važnost grupne podrške roditeljima $u$ postupku rane intervencije te nužnost primjerena oblika pomoći u procesu tugovanja djeteta (savjetovanje, kognitivno-bihevioralna terapija i usmjerena kratkotrajna terapija).

U senzorne i tjelesne potrebe autorica svrstava oštećenje sluha, oštećenje vida, gluhosljepoću, Tourette sindrom te mišićnu distrofiju. Ona $u$ procesu podrške $u$ učenju učenicima s oštećenjem sluha navodi tri pristupa: govornu komunikaciju, znakovnu komunikaciju te komunikaciju uz pomoć govora i znakovnoga jezika. Podrška u učenju i poučavanju učenicima s oštećenjem vida pruža se upotrebom Braillova pisma, dok se kod učenika s Tourette sindromom koristi pristup zamjene navika. Autorica kod motoričkih poteškoća, tj. mišićne distrofije, upućuje na kontinuirano praćenje zdravstvenoga stanja djeteta te nužnost suradnje školske ustanove $\mathrm{s}$ roditeljima $\mathrm{u}$ procesu prilagodbe $\mathrm{i}$ podrške nastave djetetovim mogućnostima i sposobnostima.

$\mathrm{U}$ petom poglavlju autorica se $\mathrm{u}$ smjerava na poteškoće $u$ jezičnom izražavanju. Na početku prikazuje uspješnog učitelja jezika te načine poticanja učenika uključivanjem u jezične aktivnosti. U poučavanju procesa čitanja ona razlikuje pristup usvajanja početnoga čitanja (bottom-up), pristup razumijevanja pročitanoga teksta (top-down) te interaktivni pristup. Podrška učenicima s poteškoćama čitanja pruža se u obliku: poučavanja fonologije, multisenzoričkoga i psiholingvističkoga pristupa.

Osim toga, autorica upozorava na važnost strategija podrške u prepoznavanju riječi te razvoju govora i jezika. U procesu pisanja razlikuje se tradicionalni pristup usmjeren na tekst, gramatiku i pravopis te suvremeni usmjeren na sadržaj i značenje. U procesu pisanja autorica predlaže poučavanje metakognitivnim strategijama (umnim mapama te naracijom). Smatra kako je za sve poteškoće $u$ jezičnom izražavanju važna razumna prilagodba djetetu u skladu s njegovim mogućnostima i sposobnostima.

U šestom poglavlju prikazuju se poteškoće u računanju. Autorica upozorava na važnost učitelja te školskog ozračja u poučavanju učenika matematičkim vještinama. Ona govori o najčešćim poteškoćama u svladavanju matematičkih vještina. To su poteškoće svladavanja matematičkoga jezika, pisanja simbola, osnovnih računskih operacija, povezivanja brojeva i količine, svladavanje tablice množenja, cijelih brojeva, brojenja novca i računanja vremena. Najčešće poteškoće s kojima se susreću učenici s računalnim poteškoćama jesu: orijentacija lijevo i desno, slabo pamćenje i prepoznavanje niza brojeva, slabe prostorne i organizacijske vještine, poteškoće $\mathrm{u}$ procesuiranju informacija te razumijevanje matematičkih koncepata. Autorica pri tome govori o važnosti podrške roditeljima kroz razne matematičke igre te računalne programe (program Numicon), koji učeniku mogu pomoći $u$ prevladavanju poteškoća.

U sedmom poglavlju autorica se usmjerava na ponašanje učenika u školi. 
Ona povezuje školski neuspjeh i ponašanja učenika. Predlaže poticanje pozitivnog razrednog ozračja te socioemocionalnog razvoja učenika. Navodi dva pristupa za poučavanje učenika socijalnim vještinama: bihevioralni pristup te multidisciplinarno planiranje.

Upućuje na problematiku upotrebe psiholoških stimulansa za reguliranje ponašanja učenika s poremećajem pažnje ili hiperaktivnosti. Smatra kako navedeni stimulansi dovode $u$ pitanje stručnu podršku učenicima. S obzirom na to ona predlaže promjenu ponašanja učenika primjenom bihevioralnih metoda učenja i poučavanja. Kod učenika s agresivnim ponašanjem upozorava na rizik od fizičkoga sukobljavanja među učenicima. Stoga preporučuje učiteljima da spriječe sukobe, savjetodavno razgovaraju s učenicima te im osiguraju podršku u smanjenju agresivnih oblika ponašanja.

U osmom poglavlju upućuje se na podršku učenicima s poteškoćama u razvoju primjenom informacijsko-komunikacijske tehnologije. Problematizira se učinkovitost upotrebe tehnologije te prilagodba kurikuluma (sadržaja, specifičnih dijelova kurikuluma te individualnih potreba učenika). S obzirom na to autorica učenicima s motoričkim poteškoćama preporučuje prilagodbu tipkovnice, miša te joysticka, uz upotrebu asistivne tehnologije. Preporučuje se i upotreba grafičkoga korisničkog sučelja, računalnoga programa za učenike s oštećenjem vida. Upotrebom slušnog aparata pruža se inkluzivna podrška učenicima s oštećenjem sluha $u$ uspješnom uključivanju u razredno ozračje. Učenicima $\mathrm{s}$ intelektualnim poteškoćama u poučavanju i učenju podrška se pruža multimedijalnom opremom te raznim aplikacijama na smartphoneima i tabletima. Upotrebom augmentativno-alternativne komunikaci- je, odnosno računalnoga programa Widget, osigurava se podrška učenicima s poremećajem jezika i govora. Učenicima s poteškoćama u učenju, tj. čitanju, pisanju i računanju, programska podrška osigurava se u obliku audiovizualnih nastavnih sredstava i pomagala (CD-a, MP3, OCR uređaja) te računalnih pomagala (elektronički radni listovi, govorni kalkulator).

U devetom poglavlju govori se o važnosti podrške stručnih suradnika edukacijsko-rehabilitacijskoga profila, pomoćnika u nastavi, roditelja te vanjskih institucija. Podrška stručnih suradnika pruža se u obliku individualnog rada s učenicima, savjetovanja, učenja i poučavanja, informiranja učitelja, suradnje s institucijama, drugim stručnjacima i roditeljima. Osiguravanjem pomoćnika u nastavi kroz individualni rad pruža se podrška učenicima $\mathrm{u}$ razrednom odjelu, ali autorica smatra kako učitelji nisu dovoljno educirani za provođenje ovakva oblika podrške. Roditeljima se podrška u odgoju djeteta s poteškoćama u razvoju pruža kroz informiranje i savjetovanje $u$ donošenju važnih odluka. Potiče se i važnost međuresorne suradnje raznih agencija koje pružaju individualnu podršku u obrazovanju učenika s poteškoćama u razvoju.

U desetom poglavlju autorica govori o inkluzivnoj školi te inkluzivnim oblicima poučavanja u odgojno-obrazovnoj praksi, a koji se temelje na suzbijanju diskriminacije, grupnim sastancima učitelja, izradbi individualnoga kurikuluma za učenika s poteškoćama u razvoju, suradnji sa školskim psihologom ili stručnjakom edukacijsko-rehabilitacijskoga profila te roditeljima učenika.

U knjizi Posebne obrazovne potrebe $i$ poteškoće u školi: kritički osvrt autorica daje teorijski i praktični prikaz odgoja i obrazovanja učenika s poteškoćama u razvoju na prostoru Ujedinjenoga Kraljevstva. Opisuje povijesni razvoj institucionalne podrške za učenike u razdoblju od segregacije pa sve do inkluzije. Kroz planiranje podrške od strane stručnih suradnika edukacijsko-rehabilitacijskoga profila, pomoćnika u nastavi, roditelja te vanjskih institucija, učenicima s jezičnim, matematič- 
kim te poteškoćama u ponašanju autorica naglašava prilagodbu kurikuluma te upotrebu informacijsko-komunikacijske tehnologije $u$ inkluzivnoj školi te inkluzivnim oblicima poučavanja u odgojno-obrazovnoj praksi.

Knjiga je prikladan vodič za teoretičare, znanstvenike, praktičare, učitelje, nastavnike i stručne suradnike $u$ školskim ustanovama koji se bave inkluzivnom pedagogijom, jer prikazuje iskustva iz inkluzivne odgojno-obrazovne prakse Ujedinjenoga Kraljevstva, strategije učinkovita poučavanja i učenja te ostvarivanje individualiziranoga kurikuluma učenika s poteškoćama u razvoju.

Andrej Hodonj

https://doi.org/10.5559/di.27.1.10
Marina Dajbić,
Jadranka Svarc,
Miguel Gonzales-
-LOureiro
ENTREPRENEURIAL
UNIVERSITIES IN
INNOVATION-SEEKING
COUNTRIES
Challenges and
Opportunities

Palgrave Macmillan, Basingstoke, New York, 2016., xxiv +253 str.

U ambicioznoj biblioteci izdavača ove knjige pod nazivom "Palgrave Studies in Democracy, Innovation, and Entrepreneurship for Growth" pojavila se konačno i jedna knjiga (četvrta u seriji) među čijim autori- ma dominiraju naše, istraživački vrlo profilirane, znanstvenice - M. Dabić i J. Švarc. A tema knjige je nadasve $\mathrm{u}$ "duhu vremena" neoliberalne razvojne paradigme - kako objasniti, ali i razvijati praksu poduzetničkoga sveučilišta u zemljama koje nisu na prvoj liniji novoga tehnološkog i inovacijskog vala - u ovome slučaju to su, uzete u komparativnoj perspektivi, Španjolska i Hrvatska. Kako već u uvodu ističu autori, svrha je knjige da se rasvijetli uloga poduzetničkoga sveučilišta u tehnološki manje razvijenim zemljama, pri čemu su dokumentirana iskustva Španjolske i Hrvatske. Ove zemlje dijele, usprkos razlikama, i mnoge zajedničke osobine u pogledu gospodarstva (npr. dominacija tradicionalnih sektora $\mathrm{u}$ gospodarstvu s naglaskom na turizam, visoka nezaposlenost mladih i sl.) i nacionalnoga inovacijskog sustava u kojem je kooperacija između industrije i sveučilišta te komercijalna primjena istraživanja nedostatna. Zato su njihova iskustva, pretpostavlja se, korisna i za ostale zemlje europskoga juga (Portugal, Italija, Grčka, Malta) ili pak za "umjerene inovatore" iz širega okružja (Rumunjska, Bugarska, Mađarska, Litva i sl.).

U skladu s tom općom autorskom intencijom, ključni ciljevi knjige razloženi su u tri koraka: 1) objasniti povijesne korijene konceptualne dvojbenosti samoga termina "poduzetničkoga sveučilišta", prisutne i kod akademskih stručnjaka, ali i tvoraca raznih politika, 2) prikazati rezultate empirijski utemeljene komparativne analize uloge poduzetničkoga sveučilišta $u$ dvije "zemlje sljedbenice", kao što su to Španjolska i Hrvatska, i, na kraju, 3) izvući relevantne zaključke o mogućoj ulozi poduzetničkoga sveučilišta u društvenim i ekonomskim uvjetima "zemalja sljedbenica", poštujući i ključne silnice gospodarstva utemeljenog na znanju i globalizacije. Struktura knjige (knjiga se sastoji od osam poglavlja) dobro oslikava ove početne ideje autorskoga tima. U prvih pet poglavlja iscrpno se obrađuje podrijetlo, koncept i funkcije poduzetničkih sveučilišta. Šesto je poglavlje posvećeno empirijskom istra- 